\title{
CULTURAL IMPORTANCE OF CHEESE TYPE FOR KINGDOM PERNAMBUCANO
}

\author{
N. K. S. SHINOHARA ${ }^{1 *}$, M. C. G. SANTOS ${ }^{2}$, S. T. C. MEDEIROS ${ }^{3}$, M. R. F. PADILHA ${ }^{1}$ and M. MATSUMOTO ${ }^{3}$ \\ ${ }^{1}$ Universidade Federal Rural de Pernambuco (UFRPE) \\ ${ }^{2}$ Universidade Federal da Paraíba (UFPB) \\ ${ }^{3}$ Centro Universitário Maurício de Nassau \\ shinoharanks@yahoo.com.br*
}

Article received October/2014 and accepted in March/2015

DOI: $10.15628 /$ holos.2015.2488

\section{ABSTRACT}

Cheese is one of the great achievements in the preservation of milk, using simple techniques and preserving important protein source in different food crops. Originally from the Netherlands, Edam cheese was introduced in Brazil in 1880 by the Portuguese colonizers, hence the name "kingdom." Currently, in the industrial production, the legislation determines that it is classified as "kingdom type ". Due to the high lipid and sodium content, this product that is most suitable in the composition of sandwiches, in sauces added to pasta
\end{abstract}

and composition along with the desserts, these associations are part of the tradition, flavors and knowledge of Pernambuco's cooking. A ball of Kingdom cheese is something that you have to give to families, especially in Christmas time and St. John, because it symbolizes the wish for happiness and prosperity in the northeastern important religious festivals calendar, where relatives and friends gather to celebrate the dates in question, putting on their tables this precious culinary heritage of Pernambuco.

KEYWORDS: kingdom type cheese, festivities, culinary heritage.

\section{IMPORTÂNCIA CULTURAL DO QUEIJO DO REINO PARA O PERNAMBUCANO}

\section{RESUMO}

O queijo é uma das grandes conquistas na conservação do leite, empregando técnicas simples e preservando importante fonte protéica em diferentes culturas alimentares. Originário da Holanda, o queijo Edam foi introduzido no Brasil em 1880, através dos colonizadores portugueses, por isso o nome "reino". Atualmente, na produção industrial a legislação em vigor, determina que seja classificado como "tipo reino". Devido ao alto teor de lipídeos e sódio esse produto alimentício é mais indicado na composição de sanduíches, em molhos adicionados às massas alimentícias e na composição junto com as sobremesas essas associações fazem parte da tradição, saberes e sabores da culinária pernambucana. Uma bola de queijo do reino é item obrigatório para presentear as famílias principalmente nos encontros natalinos e São João, pois simboliza o desejo de felicidade e prosperidade em importantes festas religiosas do calendário nordestino, onde parentes e amigos se reúnem para comemorar as datas em questão, colocando em suas mesas, esse precioso patrimônio culinário de Pernambuco.

PALAVRAS-CHAVE: Queijo do reino, festividades, patrimônio culinário. 


\section{INTRODUCTION}

The first concrete indication of the Kingdom cheese production that is known was in about $2.300 \mathrm{BC}$, due to the presence of some residue in a bowl in the early days of Egyptian civilization. It is believed that the techniques for the evolution of cheese processing started with the peoples of Central Asia and the Middle East, who had learned to preserve the sour and curdled milk naturally through the drainage of aqueous serum and addition of salt to the concentrated clots (McGEE, 2011).

In the 6th century there were perforated containers that were used for the disposal of whey and cheese production. The production involves steps that fit on the duration, intensity and temperature, for the production of foods with different textures, aromas, flavors and colors (DOMENE, 2011). The type of milk used to manufacture cheese collaborates to determine its taste, texture and process of maturation (THE CULINARY INTITUTE OF AMERICA, 2011).

Second Flandrin \& Montanari (1998), medical reports and budgets of families of workers in the 19th century in Europe, milk was rarely mentioned, due to the difficulties of conservation. The retail trade of milk was traditionally unimportant and could only be local, so it wasn't charged any tax, so that milk production was not recorded and couldn't be evaluated statistically before 1910. But the fact is that every country and region at different times have dedicated part of the milk for the production of fresh cheeses or cured (fine or special), with the aim of conserving the milk for long periods, which resulted in the preservation of nutrients and sensory quality.

Derived from the word formatium, the term "cheese" was created in the middle ages and means "cheese placed on form", where certain monasteries outdone themselves in the manufacture of cheese with strict sanitary standards. It can be manufactured with milk of different animals such as cow, goat, sheep and buffalo milk. The most commonly used milk is from the cow, for it is produced on a larger scale (CHALITA et al., 2009; ARAÚJO et al., 2011).

The cheeses are prepared by precipitation of casein from milk after the addition of Renin or another coagulant agent. The resulting curd, in the form of precipitated casein, is separated and salted, and may also be inoculated a mass of specific micro-organisms which will produce substances that add scent and flavor characteristic according to the cheese produced. In addition, proteolytic enzymes form peptides from casein, while the lipolytic produce derivates of fatty acids, which give characteristic flavors to each type of cheese. The protein fraction of this food product is about six to ten times higher in relation to milk (ARAÚJO et al., 2011).

Until the end of the 18th century, the farms and the monasteries held their recipe of the "art" of cheese manufacturing, that was passed down from mother to daughter or by the usual daily production. This led to errors of interpretation, which eventually lead to new types of cheeses. Then, the monks began to register these recipes in written form and through the interchange between the monasteries, the practice has been widespread. Only at the end of this century began the scientific study of the manufacture of cheese. In the 19th century trade spread even more with the industrial production of the product. The pasteurization process was fundamental in this event, for the hygienically and safely consumption of dairy products by the population (CHALITA et al., 2009). 
In these five centuries, Brazil has cultivated food diversity from North to South, we have a culinary wealth with indigenous, African and Portuguese influences, added to various other ethnicities that immigrated to Brazil and have contributed to the formation of Brazilian cuisine. The tradition, the history, the knowledge, the flavors, techniques and culinary practices summed are the generators of the formation of regional cultures. Increasingly, societies tend to asset valuation of their kitchen, rescuing traditional cuisine in all parts of the world, giving emphasis to regional and seasonal products and revaluing their cultural roots (ARAÚJO \& TENSER, 2006).

In Brazil, we found an important artisanal cheese production in the northeastern region, in territories where the artisanal production of dairy products predominates. Dairy farming and ways to use this raw material are presented as complementary activities, linked in a heterogeneous form. When reporting the story of artisanal cheeses in the Northeast, cultural practice of preparation of milk derivatives in the northeast was transmitted by ancestors to the female domain, and the interior of the houses was the space given to its production, exclusively for own final consumption (MENEZES, 2011).

Early in the 17th century, the Brazilian culture was influenced by the Dutch. The Dutch politician administrator with greater expression in Brazil was Maurice of Nassau that, through his policy, contributed with the development of culture, arts and Sciences, especially in the city of Recife, where were the greatest reminiscences of Dutch culture, as forts in the coastal, urban planning, bridges and townhouses (LIMA, 1999).

The Dutch explored the marketing of foods, since the time of the discoveries, when they had overseas domains, demonstrating that they were brave sailors of the 15th century, they were only a sample of a tenacious people, who knew how to aggrandize one of the nations with shortest geographic extent. The Dutch stood out in the creation of high-capacity productive dairy cattle, which makes this the best country in the production of cheeses in the world (ORNELLAS, 2000).

Originating in Holland, Edam cheeses came from Portugal and, until reach Brazil, this cheese was very different from how it was produced in its place of origin, drier, with darker color and stronger flavor. Edam Cheese was packed in cans, used as protection for the long trips. From the mid-19th century, this cheese began to be produced in Brazil, in Palmira, today Santos Dumont, in the State of Minas Gerais, with modifications in the processing. For being consumed and enjoyed by the Portuguese court that was in Brazil, this new variety of cheese was cheese "of the Kingdom". With the importation of equipment from Germany and the Netherlands, the Kingdom cheese went through changes in our territory that were successful, such as the addition of the use of annatto, which through indigenous knowledge, was kept the red shell and the habit of conserving the product in a sphere-shaped can (CAVALCANTI, 2010).

Given the above, this work had as objective to conduct a bibliographic survey about the introduction of the Kingdom cheese in Brazilian food culture and its importance as an aggregator factor in religious events in northeastern Brazil. Resulting in a cheese with small changes in sensory characteristics of origin, but that kept the name of Kingdom type cheese, to preserve the original identity of the Portuguese colony, demonstrating the social and historical significance of the Kingdom cheese as Pernambuco's food heritage. 


\section{BIBLIOGRAPHIC REVIEW}

The choice of desserts was based on tradition of weddings, baptisms, birthday, and in particular for the events of St. John and Christmas, when the Kingdom cheese is a mandatory item in this moment of important religious meeting and brotherhood.

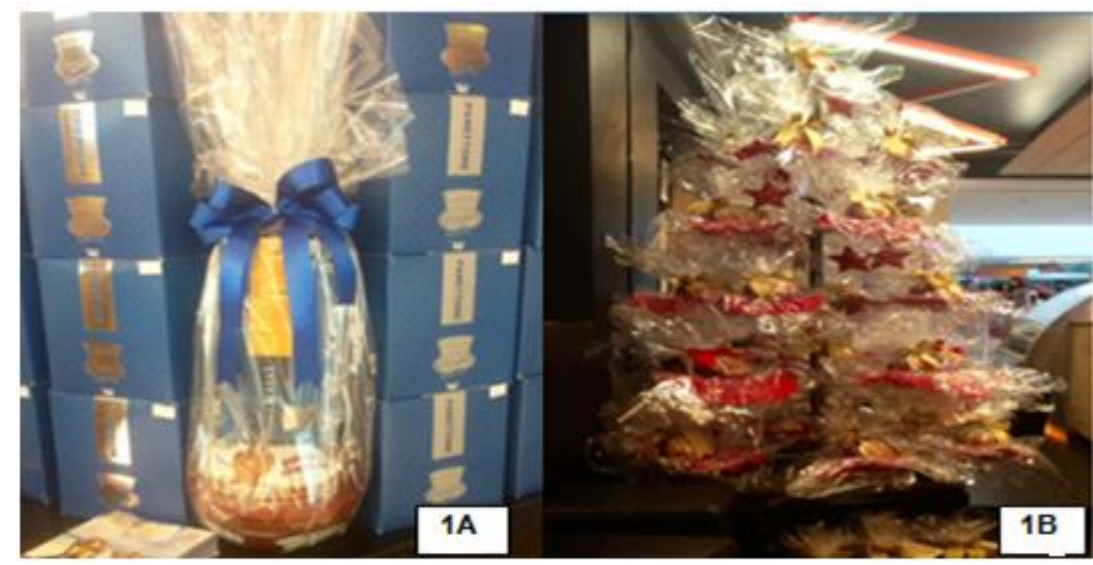

Pictures 1A and 1B: Kingdom cheese sold during Christmas time in Pernambuco. Source: Own Author

In pictures $1 \mathrm{~A}$ and $1 \mathrm{~B}$ we can see that especially at Christmastime, the cheese is sold in special packaging, containing a Kingdom type cheeseball and a box of roll cake (bolo de rolo), for example, as in Picture 1A, to be served as dessert; or in individual packages, to compose the decoration in the form of Christmas tree in a store specialized in fine cheeses in the city of Recife (Figure 1B).

According to Maior (2013) the words change and intertwined the language, to escape the specific universe of flavors and make sense in the popular imagination. The people were getting this universe of language to recreate a new and rich vocabulary. Therefore, the Kingdom cheese could not pass inert in this popular northeastern language, where that cheese, when referring to a person, as being "Kingdom type cheese", means "bald" in allusion to the image appearance of ball, hairless and shiny aspect, as we see in Picture 2.

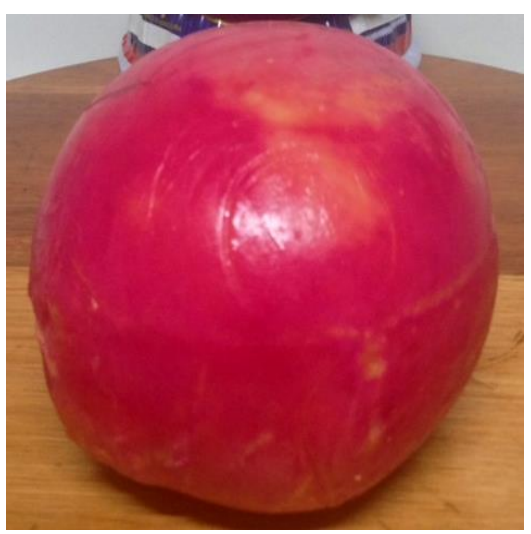

Picture 2: Kingdom type cheeseball. Source: Own Author

In pictures $3 \mathrm{~A}$ and $3 \mathrm{~B}$, we highlight the pair of Kingdom cheese and a piece of typical wedding cake of Pernambuco, that takes on its composition: butter, sugar, eggs, lemon, allpurpose flour, nutmeg, clove, cinnamon, Plum, black and golden raisins, candied fruit, cognac, 
port wine, almonds and after baked, receives an icing marble cover; that takes the beaten eggs whites, lemon juice and a large amount of sugar. Observing Picture $3 \mathrm{C}$, we have the composition of Kingdom cheese along with the roll cake (bolo de rolo), which has the following ingredients: sugar, butter, eggs, flour, guava jelly. The wedding cake and the roll cake (bolo de rolo) are traditional confectionery delicacies from Pernambuco (CAVALCANTI, 2010).

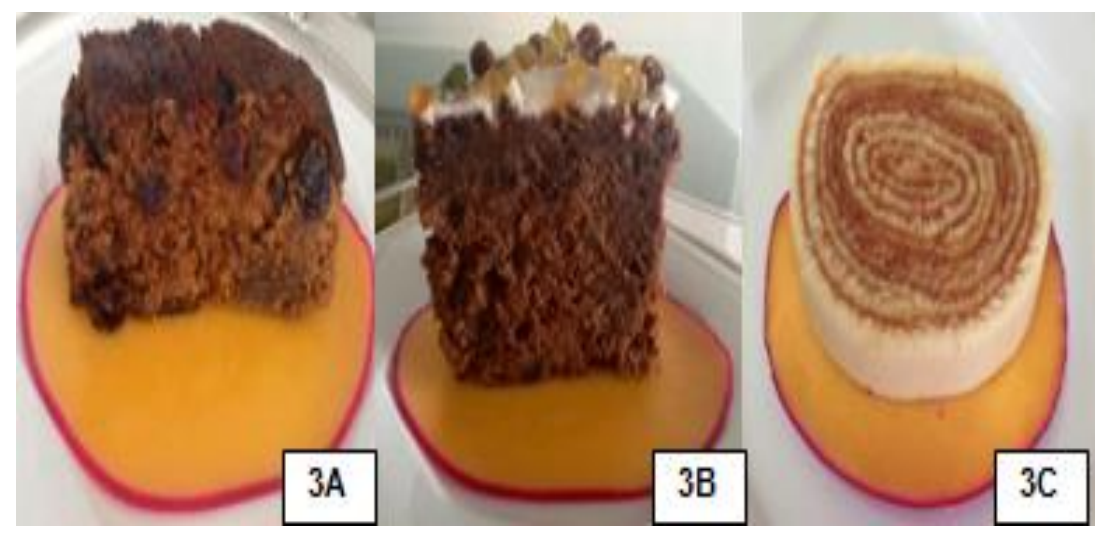

Picture 3A, 3B and 3C: Kingdom cheese on the composition of desserts. Source: Own Author

According to the information from Leal (2013), kingdom cheese consumption in Pernambuco is approximately $700 \mathrm{~T} / \mathrm{year}$, being $85 \%$ of this volume concentrated in the tiers of the end of the year. In the State of Bahia, where consumption is similar to that of Pernambuco, the main feature is the concentration distributed between the June festivals and Christmas.

Moacir Vidal is an owner of a dairy farmer for 15 years in the State of Minas Gerais, he is engaged in the manufacture of the Kingdom cheese and tells that, in the Northeast, the product is more than a gift, because it means prosperity for those who receive it, and this is extended to their families. This cheese was originated in Holland, imported by Portugal, and then came to Brazil, so it was a cheese that came from the realm, tradition which is preserved until today. To receive a kingdom cheese means a desire for happiness and prosperity. On that time of year, the dairy billing increases around $20 \%$ because of the June festivals of the northeast of the country. The main market is Bahia, followed by Sergipe, Pernambuco and Paraiba $(G 1,2013)$.

According to Freyre (2007), one cannot speak of the northeastern cuisine without giving due prominence to the candy. It was there that the Brazilian sugar reached the splendor. The importance of sugar cane in the region (their dominance lasted for 400 years, from the 16th to the 20th century) made this part of the country a reference of the national confectionery. Sugar molded our way of being and our soul. "Without the sugar it is not understood the man in the Northeast".

On the desserts presented (pictures $3 \mathrm{~A}, 3 \mathrm{~B}$ and $3 \mathrm{C}$ ), we note that the famous pair of dessert is due to set a piece of salty cheese and a piece of candy with a lot of sugar, what characterizes the culinary tradition of the Northeast, which is to pacify the sweet with the salty or vice versa. According to Quintas (2010) the salt and sugar, the two poles of the palate, became known by Indians and Africans, through the Portuguese influence, people adept at this hybridity in cooking. 
In Ceara, in the city of Fortaleza, according to Campos (1996) there are records that date from the 40s, of the last century. The clientele, housewives of fortunate families, was disputed by the main grocery stores that were specialized in different food products. Campos describes in his book a shopping list on the preferences of that era, in which the Kingdom cheese of a particular brand topped that list. The list was long, presumable and designed to facilitate the purchases that would be used for the reception of a larger group or special guests.

According to Menezes (2011), even today, is part of the countryside man's tradition giving as a present a cheese to visitors, relatives, friends and cronies who inhabit in urban spaces and/or other regions. So, this cultural practice happens when the visit of a countryside man to cities. This fact is appreciated by recipients, that, when taste such ingredient, remember their diet in rural areas or in childhood, bringing moments of homesickness and peace.

\subsection{Production technology of Kingdom Cheese in Brazil}

The sensory attributes of Kingdom cheese are described in Instruction no 68, December 12, 2006 that classify the Kingdom cheese. In this standard, the Kingdom cheese is presented as a cheese from pasteurized milk of semi mass cooked, semi-hard consistency, not very elastic and greasing tending to drought; straw-yellow or yellowish homogeneous color, and may have pinkish tonality; thin and smooth bark, of reddish or rosy color, with or without paraffin; characteristic odor; gently sweet and spicy flavor; open texture, with clear boundary eyes of bright background, approximately $3 \mathrm{~mm}$ in diameter (BRAZIL, 2006).

The RIISPOA of the Ministry of Agriculture, Livestock and Food Supply, complements the information defining the Kingdom cheese must have a weight between 1.8 to $2.2 \mathrm{~kg}$, spherical and properly matured for a minimum of 2 months. In both standards the Kingdom cheese is defined as "Kingdom cheese" for authorization of production and marketing in Brazil, as we observed in Picture 4A (BRASIL, 1996).

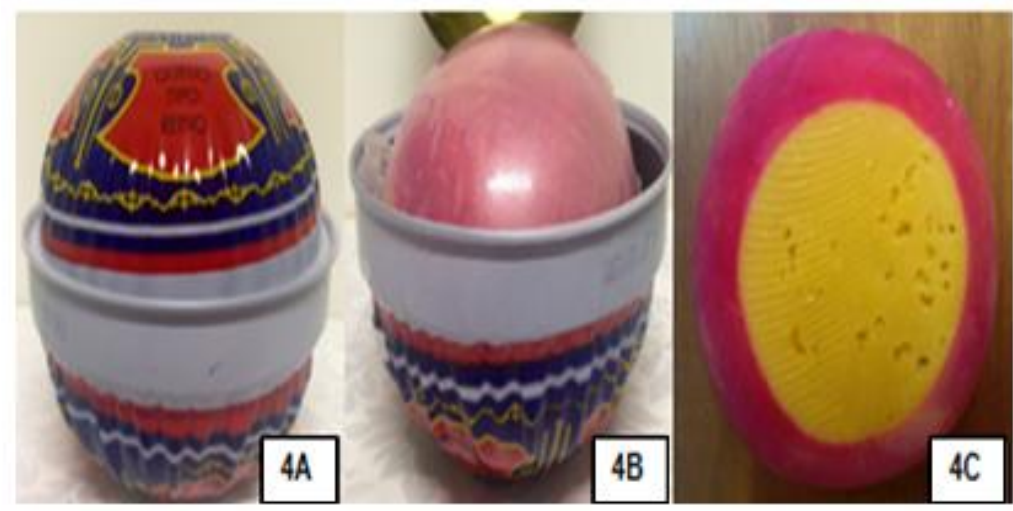

Pictures 4A, 4B and 4C: packaging and presentation of the Kingdom cheese. Source: Own Author

In Picture 4B we see how the Kingdom cheese presents itself in heat shrinkable nylonpoly packaging inside the Bowl-shaped Tin, and in Picture $4 C$, the mass of yellow appearance with a rosy layer on the outside of the cheese.

The consumption of Kingdom Cheese was broadcast to the States of southeastern Brazil, which led to the inclusion of two separate products on the market: a traditional cheese, intended for consumers in the Northeast region, and a cheese with technology adapted, with milder flavor 
and aroma, intended for consumers in the Southeast. The first requires a longer maturation, which adds value to it and results in a cheese with peculiar sensory characteristics, that, linked to its packaging and traditional bark, strengthen its international standard (FURTADO, 2008).

In the States of southeastern Brazil, the Kingdom cheese is marketed, usually over chilled and controlled temperature, and in States in the Northeast region of Brazil is often sold at ambient temperature. The different forms of storage of cheese directly influence on the maturation process, and consequently the development of flavour. Thus, to monitor physical, chemical, physicochemical and sensory changes that occur during maturation and shelf life of this product becomes critical to ensure its final quality (TAVEIRA, 2013).

As for sensory testing, tasting notes under the thin shell have soft and flexible texture and a sweet buttery flavor, getting tastier and steady over time. You can enjoy comfortable in sandwiches, grilled, grated, or served at breakfast with chocolate and eggs, as they do in the Netherlands with the Edam (HARBUTT, 2010).

The Kingdom cheese can be prepared according to the procedure described by Taveira (2013). Bovine milk is subjected to the heat treatment of pasteurization $\left(72^{\circ} \mathrm{C} / 15\right.$ seconds) with $3.0-3.1 \%$ of fat per $\mathrm{m} / \mathrm{m}$, and are added nitrate, annatto dye, yeasts and thermofílicos-oxidizers, calcium chloride and coagulant, respectively. Then are forwarded to coagulation $\left(32-34^{\circ} \mathrm{C} / 45\right.$ $\mathrm{min}$ ) and is later performed the cutting of the curds (grain 2-3).

The first mix occurs slowly for 12-15 minutes and then turns out the partial whey removal. The second mix is performed quickly for 10-20 minutes to prevent the formation of agglomerates, causing expulsion of serum that is called total whey removal. The pre-pressing occurs with 6.5 pounds/inch ${ }^{2}$ for 10 minutes; in the forming the dough is cut into blocks and placed in the stainless steel forms of characteristic ball format of Kingdom cheese. On the pressing happens to whey removal for about 40 minutes (without whey removal machine), salting in brine occurs after 20 hours of pressing (Picture 5).

After the salting of 24 hours, it happens the drying for 10 days. The painting is done with litmus solution $(30 \mathrm{~mL} / 100 \mathrm{~g})$ and occurs after the scraping and washing of the cheeses. The maturation occurs for at least 60 days and the cheeses are vacuum packed in thermo-shrinking packaging-poly nylon. The basic technology of the manufacture of the Kingdom cheese is presented in Picture 5.

The producer Moacir Lucas Vidal, since 1992, produces the brands of Kingdom cheese Milano, Butterfly and Palmira, in the municipality of Antônio Carlos, located in the Serra da Mantiqueira, in Minas Gerais. He produces an average 60 tons of Kingdom cheese per month, of which $40 \%$ of the total is intended for Pernambuco and Bahia. The biggest secret is milk produced rangeland of Serra da Mantiqueira, which has specific micro-organisms of the area. These beings promote a top quality cheese, which makes the differential (LEAL, 2013).

The cheese is, without doubt, an expression of the milk, enzymes and micro-organisms that constitute its main ingredients. But are also, above all, an expression of the ability and the affection of the cheesemaker, who chooses the ingredients and the Orchestra its many chemical and physical transformations (McGEE, 2011). Gradually, the careful observation and the ingenuity of the producers turn it into something that goes beyond simple physical nutrition, it is the 
intense expression of pastures, herd health, climate change and microorganisms in fermentors timeline.

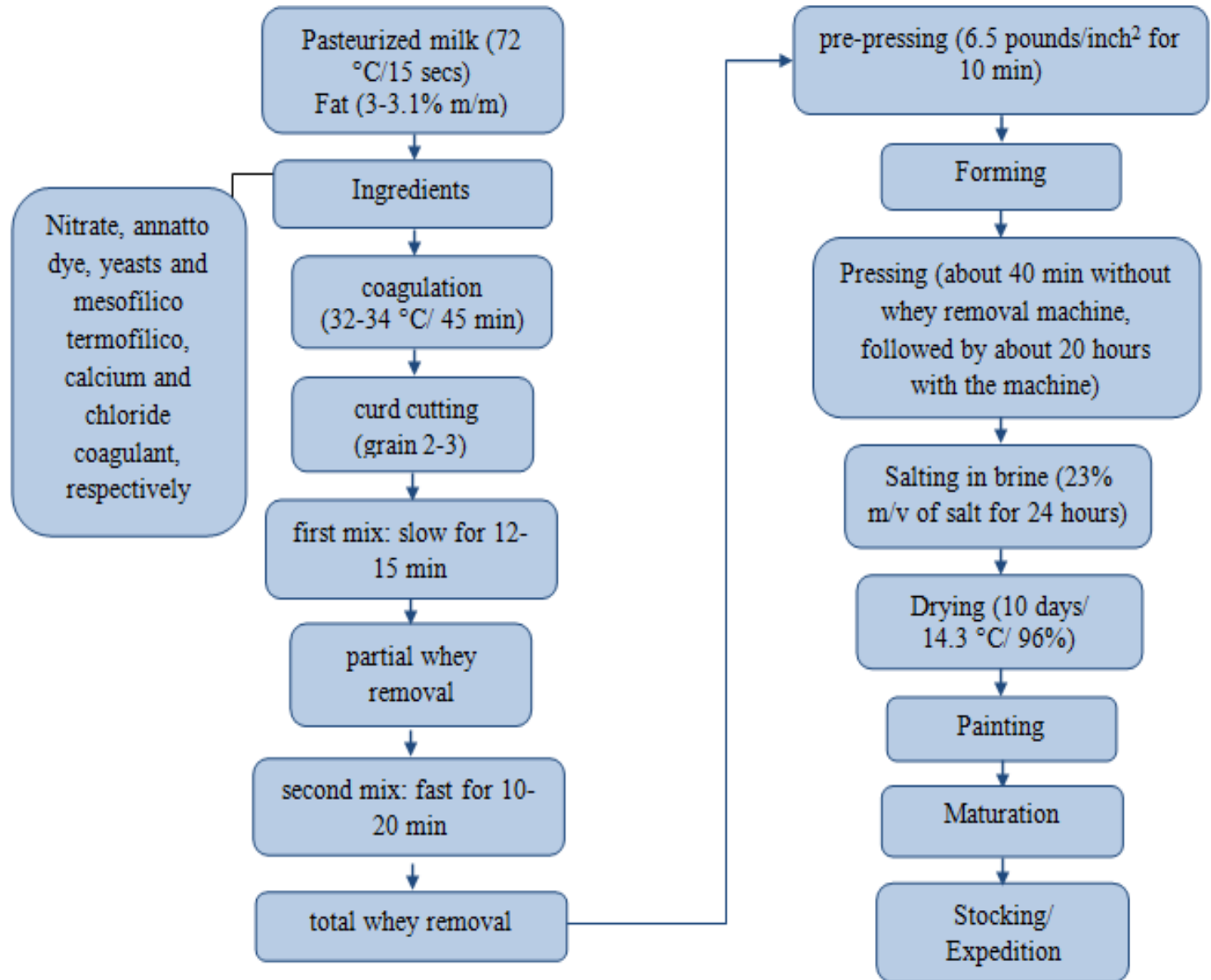

Picture 5- Basic technology of manufacture of the traditional Kingdom cheese. Source: Taveira, 2013

\section{MATERIALS AND METHODS}

Bibliographic searches were carried out in books, journals and virtual sites, seeking information about the history of the Kingdom type cheese, its origin, its introduction in Brazil and influence on Brazilian cuisine. Desserts from Pernambuco cuisine culture were made; they are traditionally served along with the cheese and later were promoted photographic records. The Kingdom cheese was the common element in the different versions of the confectionery from Pernambuco presented in this article.

\section{CONCLUSION}

The Kingdom cheese is important in Pernambuco's cuisine, mandatory attendance at the table of Pernambuco, mainly in St. John festivities and on Christmas supper. This culinary product went through the time of colonization, of the Empire and the Republic and reached the democratic State of law, as an aggregator in the different layers of society in the State of Pernambuco and to the history of the cheese dairy in Brazil. 


\section{BIBLIOGRAPHICAL REFERENCES}

1. ARaújo, W. M. C, MOntebello, N. P., Botelho, R. B. A., BORGo, L. A. Alquimia dos Alimentos. Editora Senac, Brasília: p. 259-282, 2011.

2. ARAÚJO, W. M. C.; TENSER, C. M. R. (org.). Gastronomia: Cortes \& Recortes. $2^{\text {a }}$ ed. Brasília: Editora Senac, 264 p, 2006.

3. BRASIL. Ministério da Agricultura, Pecuária e Abastecimento. Portaria no 68, de 12 de dezembro de 2006. Aprova regulamentos técnicos de identidade e qualidade dos produtos lácteos. Diário Oficial [da] República Federativa do Brasil.

4. BRASIL. Ministério da Agricultura, Pecuária e abastecimento. Secretária Nacional de Inspeção de Produtos de Origem Animal. Portaria n. 146, de 07 de março de 1996. Regulamentos Técnicos de Identidade e Qualidade dos Produtos Lácteos. Diário Oficial [da] República Federativa do Brasil, Brasília, n. 146, 3977 p.

5. CAMPOS, E. A. A Gramática do Paladar. Fortaleza: Casa José de Alencar, 128 p, 1996.

6. CAVALCANTI, M. L. M. História dos Sabores Pernambucanos. Recife: Fundação Gilberto Freyre, 356 p, 2010.

7. CHALITA, M. A. N., SILVA, R. O. P., PETTI, R. H. V., SILVA, C. R. L. Algumas Considerações sobre a Fragilidade das Concepções de Qualidade no Mercado de Queijos no Brasil. Informações Econômicas, SP, v.39, n.6, p.77-88, 2009.

8. The Culinary Intitute of America. Chef profissional: Instituto Americano de Culinária. $4^{\mathrm{a}}$ ed. São Paulo: Editora Senac, 1236 p, 2011.

9. DOMENE, S. M. A. Técnica Dietética: teoria e aplicações. $1^{\text {a }}$ ed. Rio de Janeiro: Editora Guanabara Koogan, 350 p, 2011.

10. FLANDRIN, J. L., MONTANARI, M. História da Alimentação. $2^{a}$ ed. São Paulo: Editora Estação Liberdade, 885 p., 1998.

11. FREYRE, G. Açúcar: Uma Sociologia do Doce, com receitas de bolos e Doces do Nordeste do Brasil. São Paulo: Global, 270 p, 2007.

12. FURTADO, M. R. A. Caracterização histórica, tecnologia de fabricação, características físicoquímicas, sensoriais, perfil de textura e de comercialização do queijo Reino- $82 p$. Tese (Pósgraduação em Ciência e Tecnologia do Leite e Derivados)- Universidade Federal de Juiz de Fora, Minas Gerais, 2008.

13. G1 (2013). Festas juninas do NE alavancam produção de queijo do reino em MG. In: http://g1.globo.com/economia/agronegocios/noticia/2013/06/festas-juninas-do-nealavancam-producao-de-queijo-do-reino-em-mg.html

14. HARBUTT, J. O Livro do Queijo: Os Melhores do Mundo. $1^{\text {a }}$ ed. São Paulo: Editora Globo, 352 p, 2010.

15. LEAL, W. (2013). Muito além das festas de final de ano. In: http://www.diariodepernam buco.com.br/app/noticia/gastro/2013/10/03/interna_gastro,465935/queijo-do-reino-muitoalem-das-festas-de-fim-de-ano.shtml.

16. LIMA, C. Tachos e Panelas: Historiografia da Alimentação Brasileira. Recife: Editora Aurora, 309 p, 1999. 
17. MAIOR, M. S. Alimentação e Folclore. Recife: Editora Massangana, 156 p, 2013.

18. McGEE, H. Comida \& cozinha: Ciência e Cultura da Culinária. $1^{\text {a }}$ ed. São Paulo: WMF Martins Fontes, 992 p, 2011.

19. MENEZES, S. S. M. Queijo Artesanal: Identidade, Prática Cultural e Estratégia de Reprodução Social em Países da América Latina. Revista Geográfica de América Central. Número Especial EGAL, Costa Rica, p. 1-16, 2011.

20. ORNELLAS, L. H. A Alimentação Através dos Tempos. $1^{\text {a }}$ ed. Florianópolis: Editora UFSC/EDUFSC, 306 p., 2000.

21. QUINTAS, F. A Saga do Açúcar. $1^{\text {a }}$ ed. Recife: Fundação Gilberto Freire, 260 p., 2010.

22. TAVEIRA, L. B. Aspectos Físico-químicos e Sensoriais do Queijo do Reino Maturado sob Diferentes Concentrações, Visando a Exportação. 118p. Dissertação (Pós-Graduação em Ciência e Tecnologia do Leite e Derivado)- Universidade Federal de Juiz de Fora, Minas Gerais, 2013. 